\title{
Risk Communication and External Emergency Plan in Angra dos Reis, Brazil
}

\section{Raquel Dalledone Siqueira da Cunha, Delvonei Alves de Andrade}

Nuclear and Energy Research Institute, Instituto de Pesquisas Energéticas e Nucleares/Universityof São Paulo, USP, São Paulo, Brazil Email: raqueldalledonesiquera@gmail.com,delvonei@ipen.br

How to cite this paper: da Cunha, R.D.S. and de Andrade, D.A. (2016) Risk Communication and External Emergency Plan in Angra dos Reis, Brazil. World Journal or Nuclear Science and Technology, 6, 301308.

http://dx.doi.org/10.4236/winst.2016.64027

Received: September 13, 2016

Accepted: October 23, 2016

Published: October 26, 2016

Copyright $\odot 2016$ by authors and Scientific Research Publishing Inc.

This work is licensed under the Creative Commons Attribution International

License (CC BY 4.0).

http://creativecommons.org/licenses/by/4.0/

\begin{abstract}
The presence of a potentially hazardous facility in a community demands several safety procedures. Bringing risk communication among those actions may help the population that lives near the facility feel more confident and have the required knowledge on how to behave in an emergency situation. A research performed in Angra dos Reis, RJ, Brazil, where a nuclear power plant is located, shows that there is a lack of information and awareness about the emergency plan.
\end{abstract}

\section{Keywords}

Risk Communication, Emergency Plan, Nuclear Power Plant

\section{Introduction}

New chemical and nuclear technologies are associated with the potential to cause lasting and catastrophic damage to the planet and for present and future generations. These technologies are the basis for rejection in fact, not be familiar to most people and therefore become incomprehensible [1] [2].

To address this rejection of a hazardous installation, it is necessary to inform the public about the risks posed and known preparation procedures and emergency response.

The process of reporting on risks to health, safety and the natural and urban environment is called risk communication [3].

Risk communication is based on dialogue between the company and the public. It is an exchange of information that takes place between stakeholders, with special attention to the perception people have of the risks [3]

In Brazil, the existing nuclear power plant is located in Angra dos Reis, the southern coastal city in the state of Rio de Janeiro. Angra Nuclear Power Plants (CNAAA), with 
plants Angra I and Angra II.

The municipality has an area of 825 square kilometers and a coast very trimmed by 365 islands. According to the estimate of the Brazilian Institute of Geography and Statistics (IBGE) in 2015, which has about 188,000 inhabitants. In a large distance between $1 \mathrm{~km}$ and $5 \mathrm{~km}$ from the Angra I plant is home to about 19,200 people [4] [5] [6].

The aim of this paper is to show the efficiency of risk communication with the local population. The research sought to know how the information reaches the target audience and ownership information, how the public would react in an emergency situation at the nuclear plant.

\section{Literature Review}

\subsection{Risk Communication}

Risk communication is a resource that can be used to provide the public with clear and sufficient information in order to get them closer to understanding the technical aspects of the risks to which they are exposed. The more information and knowledge you have, the more the public will know how to proceed and to protect themselves in an emergency situation [3] [7].

Participating in debates and decisions that concern us and affect our lives in relation to safety, health and values is one of the principles of democracy, and also one of the principles of risk communication. It is necessary that people have access to information and that there is an exchange of knowledge in which opinions are formed and participation is effective and collaborative [8] [9] [10].

Risk communication requires a commitment to listen, understand and learn from the audience to whom the message is addressed. This is because the goal is not only to send a message, but to talk about the dangers posed by a certain facility, according to experts, and risks that this same installation offers, from the perspective of people living nearby. It is a process that should be based on trust, respect between the parties and comprehensive exchange of information [3] [8].

Generally, the perception of risk is based on intuition and is influenced by the memory of past events and imagination of future events. Often this perception comes from dangers known through media, which tends to prioritize the transmission of threats and setbacks that happen around the world [1] [2].

Many experts believe that the greater or lesser risk perception by the public and their behavior in relation to this perception are influenced by the interaction of risk events and psychological, social and cultural processes [11].

\subsection{Emergency Preparedness and Response and Emergency Plan}

Any emergency, whether conventional or nuclear, will have a better response if there is a prior preparation of this response. The most effective action involves coordination and definition of responsibility and authority among the various factors responsible for the emergency response. In case of a nuclear emergency, the response involves several national agencies, all levels of government and international organizations [12]. 
In Brazil, nuclear power plants, to be built, must have their location, as well as the license for construction and permits for the use of nuclear materials for both initial and permanent operation, authorized by the National Nuclear Energy Commission (CNEN). This is all specified in the norm CNEN NE 1:04 - CNEN Resolution 15/02 of December 2002.

The same norm requires a description of the local emergency plan in its Final Report Security Element (RFAS) to ensure, within the guidelines given by the International Atomic Energy Agency (IAEA), the safety of workers and the general population in an emergency [13].

Since 1958, the International Atomic Energy Agency (IAEA) has a security programme for the nuclear area, to establish safety standards to ensure protection of health and reduce the risks offered to property and the environment [12].

The purpose of creating a standard in the area of security is to make the Member States across the Agency, through their governments, regulators and operators, ensure that the use of radioactive materials and nuclear sources is done in a safe, ethic and beneficial way [12].

The External Emergency Plan (PEE) of the State of Rio de Janeiro for the case of a nuclear emergency at nuclear power facilities Almirante Alvaro Alberto is in its fifth review in 2016 and was approved by Decree No. 44384, September 11, 2013. Several agencies of the federal government, the states of Rio de Janeiro and Sao Paulo and the municipalities of Angra dos Reis and Paraty are involved in the preparation and application of this plan, as well as private institutions and non-governmental organizations [14].

\section{Field Research}

The aim of this study is to observe the reach of the diffusion of PEE and to analyze whether the population has information on how to act in case of an emergency.

The relevance of this research is partly due to the fact that the more and better people know the procedures to follow in case of an accident at the nuclear plant, smaller is the chance of panic taking over and bigger is the confidence in the institutions responsible for the emergency plan.

Interviews with the public were held September 11 to October 6, 2015, in public places, homes and workplaces. The choice of respondents was random, according to the willingness to participate.

Data for this study were collected through questionnaires with open and closed questions, referring to the knowledge of External Emergency Plan; information on how to act in an emergency situation; fears and concerns; and the means by which the local people is informed.

In total, 50 people were interviewed in neighborhoods with municipal schools and in the center of the city, and in the beaches that are part of the Emergency Planning Zone 3-ZPE 3 (Guariba) and Emergency Planning Zone 5-ZPE 5 (Praia Vermelha) that have no schools and together have about 1200 people living there in low season [6]. 
Emergency Planning Zones are circular areas with radius of $3 \mathrm{~km}, 5 \mathrm{~km}, 10 \mathrm{~km}$ and $15 \mathrm{~km}$ from the installation of Angra I. According to the proximity of the CNAAA, it is established the risk to which a particular region is exposed in order to facilitate the planning of emergency actions [14].

The ZPE 3 and ZPE 5 are considered areas of preventive action, i.e., areas where protection measures are immediate, in case of accident, to seek lower risk to the health of the population [14] [15].

Special attention, reflecting in a larger number of respondents, was given to the Frade neighborhood as it is the most populated, with about 18,000 residents within a radius of up to $5 \mathrm{~km}$ of the nuclear power plant district [6].

\section{Analysis of Data}

Among the 50 surveyed three attended elementary school and 18 have completed middle school. People who have not completed high school are 11, whereas with complete high school, 14. Three are the respondents with higher education. Only one respondent declared illiterate. Women are the majority of respondents 27/50.

The level of schooling has an influence on the respondent's capacity to understand the PEE, since all the material distributed to the population, explaining about it, is written. If people are illiterate or if they can read but do not understand the meaning of the text, it is useless.

\section{Fears and concerns}

The possibility of a nuclear accident did not prevail among the answers given by respondents about their fears and concerns. Even with the history of the nuclear accident in Chernobyl (Ukraine) in 1986 and Fukushima (Japan) in 2011, according to one interviewee, "there is already so much to worry about that we try to forget the plant."

Violence was the main concern. Education and safety of children came in second place and then health. Only after that came the fear of a nuclear accident.

However, four of the ten people who identified this issue as a worry have "nuclear accident" as their only fear.

Fear of unemployment is in fifth place. Next comes the concern with bills and debts, then the fear of traffic accidents. Concern for parents and work issues appear together in eighth place. Sliding slope, lack of water, wind, lack of infrastructure and economic situation share position with fears of a betrayal from their husband and Brazil going to war.

These life issues do not cause any fear or any concern for 9/50 of the respondents, and two respondents did not answer the question. Respondents could mark as much alternatives as they wanted for this answer.

Even if the possibility of a nuclear accident is not the main focus of concern on the daily life of the respondents, the need to know what and how to do in an emergency situation is critical for the safety of the population

\section{Information mechanisms}

The population of Angra dos Reis has several mechanisms to receive information 
about the PEE. On the 10th of each month, at $10 \mathrm{am}$, eight sirens from Eletronuclear (ETN), scattered through neighborhoods that are part of the Emergency Planning Zones 3 and 5, are activated. This is to familiarize the population with the sound of the alarm and to test the equipment.

Itaorna Visitors Information Center hands educational brochures that talk about nuclear power and the emergency plan. The center is open to locals and tourists, with displays of explanatory videos, models and photographs.

Each year, ETN prints and distributes four versions of the calendar with specific information for residents of Praia Brava (ZPE 1), an area under its responsibility; for residents of the ZPE 3 and 5; for residents of the ZPE 10 and 15; and for distribution among the general population and visitors of the Convent of Carmo, historic building in the center of Angra dos Reis, restored and maintained by the company.

Every two years there is the General Simulation Exercise, where an accident situation is simulated and institutions involved in PEE act as if it was real. This exercise is a practice for the case of a real incident and serves to identify gaps in procedures and to improve the emergency plan.

Field research shows that among the mechanisms used by the public to get informed, television is the most utilized, 44/50. Radio is little used by the surveyed population, $13 / 50$. Newspapers are an information vehicle used by more than half of respondents (26/50).

However, these mechanisms are not used on a recurring basis to promote the PEE. Newspapers, brochures, billboards and ads on radio and television are means used only to announce the General Simulation Exercise.

Part of the respondents, 21/50, have read the booklet on nuclear energy, the power plant and the emergency plan (PEE).

The only mechanism that is constantly employed and especially directed to the target audience is the calendar. It contains specific instructions and explanations about PEE and is distributed among residents of ZPE 1, 3, 5, 10 and 15. Among those surveyed, 27 reported receiving the calendar in 2015, 15 have not received it and eight did not answer the question.

Among all respondents who receive the calendar, 16 claim to know what to do in an emergency situation. Among the 15 participants who did not receive the calendar, only one claimed to know how to proceed in case of emergency. These data show that the calendar contributes to the dissemination of information (Figure 1).

\section{Population level of knowledge}

In case there is an accident at the nuclear power plant Almirante Alvaro Alberto and the alarm is triggered 17/50 feel prepared to act properly, 29 of respondents said they did not know what to do and 4 did not answer the question (Figure 2).

Go to the meeting point; wait for orientation from Civil Defense; turn off the power before leaving the residence; "Do not leave the house, put wet cloths on doors and windows, stock up on food and wait for the guidance from the Civil Defense"; "Turn off the circuit breaker, stay at home or go to the meeting point"; "try to stay away from 


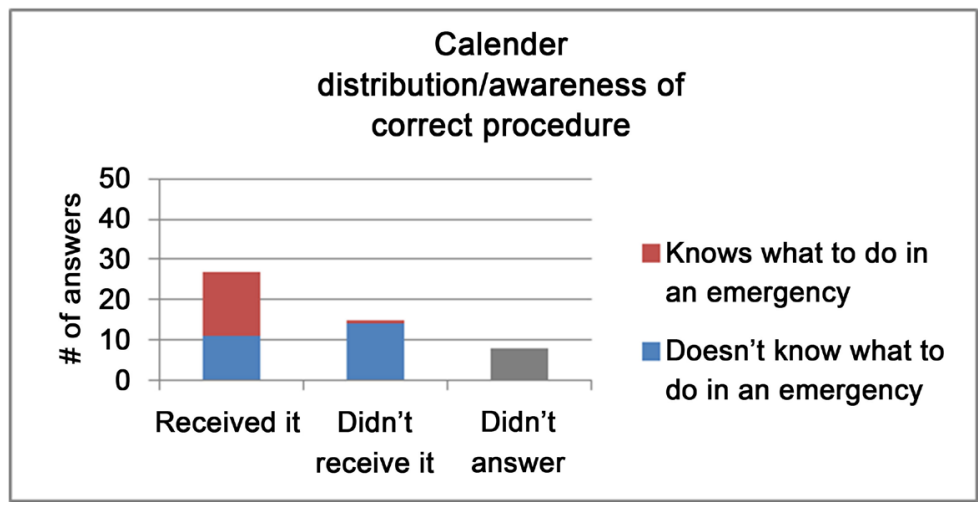

Figure 1. Calendar distribution/awareness of correct procedure.

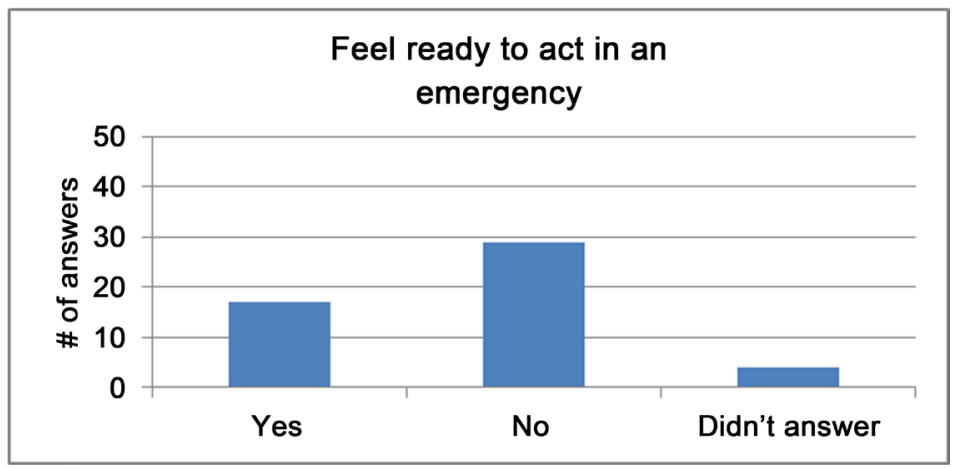

Figure 2. Feel ready to act in an emergency.

the plant and help the people that were evacuated."

These are some of the answers given by those who claim to know how to act in case of an accident at the plant. However, lack of faith in the effectiveness of the emergency plan makes some of these people have doubts if they would follow the recommendations.

Among the problems presented to follow correct procedures are the lack of escape routes; the belief that "if there is a leak, nobody will leave Angra. People who are infected will be isolated"; "The emergency plan does not work, we will have no time to evacuate."

From these statements one can infer that knowing the action that should be taken at a moment of emergency, in this case, does not necessarily mean following the procedure correctly.

\section{Conclusions}

Research shows that the calendar helps in the dissemination of information, but the lack of trust in institutions and in the emergency plan jeopardizes the effectiveness of measures taken to minimize the consequences of a possible accident.

ELETRONUCLEAR and Civil Defense of Rio de Janeiro do emergency communication, but not risk communication. It is necessary to involve the public in the development process of the emergency plan, through a partnership, an exchange process. 
The training of the institutions involved in the PEE during the course of the simulation exercise helps the overall improvement of the emergency plan, but does not guarantee its effectiveness regarding the actions with the population.

Risk communication is important for the population of Angra dos Reis. Only through dialogue between ELETRONUCLEAR, participating institutions in the PEE and the public it will be possible to know the fears and expectations of the population and to present how risks are managed by the company.

Lectures at schools, contests, and radio and TV programs are some of the ways institutions may approach the population and establish a dialogue. Proximity allows for a mutual awareness of the parties involved in the process and enables the development of the necessary trust for risk communication.

While a relationship of trust between plan participants and the public is not established, there is no guarantee that the procedures for the safety and health of the population in an emergency situation will be met.

\section{Acknowledgements}

This research project was sponsored by ELETROBRAS ELETRONUCLEAR through the 012/2013 notice CAPES/ELETRONUCLEAR.

\section{References}

[1] Slovic, P. (2004) Perception of Risk. In: Slovic, P., Ed., The Perception of Risk, 4 Edition, Earthscan Pub-lications Ltd., London, 220-231.

[2] Fischhoff, B., Slovic, P., Lichtenstein, S., Read, S. and Combs, B. (2004) How Safe Is Safe Enough? A Psychometric Study of Attitudes toward Technological Risks and Benefits. In: Slovic, P., Ed., The Perception of Risk, 4 Edition, Earthscan Publications Ltd., London, 80103.

[3] Santos, S. (1990) Developing a Risk Communication Strategy. Journal AWWA, 82, 45-49.

[4] www.cidades.ibge.gov.br/xtras/perfil.php?lang=\&codmun=330010\&search=rio-de-janeiro/ angra-dos-reis

[5] Interview with Marcos Vinicius Major BM, Assistant Coordinator-Nuclear Emergency Control and Coordination Center. Angra dos Reis, RJ, May, 20, 2014.

[6] http://www.eletronuclear.gov.br/Aempresa/CentralNuclear.aspx

[7] Santos, S. and Folwarkow, S. (1991) Are You at Risk? Petroleoum Today, Vol. 2, No. 1.

[8] Covello, V.T., McCallum, D.B. and Pavlova, M. (1989) Principles and Guidelines for Improving Risk Communicaton. In: Covello, V.T., McCallum, D.B. and Pavlova, M., Eds., Effective Risk Communication, Plenum Press, New York, 3-16. http://dx.doi.org/10.1007/978-1-4613-1569-8 1

[9] Ferrari, V. (2000) Democracia e Informação no Século XX. In: Guimarães, C. and Junior, C., Org., Informação e Democracia, Editora UERJ, Rio de Janeiro, 163-209.

[10] Vaughan, E. (1995) The Significance of Socioeconomic and Ethnic Diversity for the Risk Communication Process. Risk Analysis, 15, 169-180. http://dx.doi.org/10.1111/j.1539-6924.1995.tb00311.x

[11] Kasperson, R.E., Renn, O., Slovic, P., Brown, H.S., Emel, J., Globe, R., Kasperson, J.X. and Ratick, S. (1988) The Social Amplification of Risk: A Conceptual Framework. Risk Analysis, 
8, 177-187. http://dx.doi.org/10.1111/j.1539-6924.1988.tb01168.x

[12] IAEA Safety Standards for Protecting People and the Environment (2015) Preparedness and Response for a Nuclear or radiological Emergency. General Safety Requirements. Vienna.

[13] Norma CNEN NE 1.04-Resolução CNEN 15/02; Dezembro/2002.

[14] Plano de Emergência Externo do Estado do Rio de Janeiro (PEE/RJ) para caso de emergência nuclear nas instalações da Central Nuclear Almirante Álvaro Alberto (CNAAA). Secretaria de Estado da Defesa Civil-SEDEC, Decreto no 44.384 de 11 de setembro de 2013.

[15] IAEA (1997) Method for the Development of Emergency Response Preparedness for Nuclear or Radiological Accidents. VIENNA, IAEA-TECDOC-953.

Submit or recommend next manuscript to SCIRP and we will provide best service for you:

Accepting pre-submission inquiries through Email, Facebook, LinkedIn, Twitter, etc. A wide selection of journals (inclusive of 9 subjects, more than 200 journals)

Providing 24-hour high-quality service

User-friendly online submission system

Fair and swift peer-review system

Efficient typesetting and proofreading procedure

Display of the result of downloads and visits, as well as the number of cited articles

Maximum dissemination of your research work

Submit your manuscript at: http://papersubmission.scirp.org/

Or contact wjnst@scirp.org 